\title{
ANALISIS PROGRAM TANGGUNG JAWAB SOSIAL PT BUMI KONAWE MINING
}

\author{
Analysis of Corporate Social Responsibility Program of PT Bumi \\ Konawe Mining

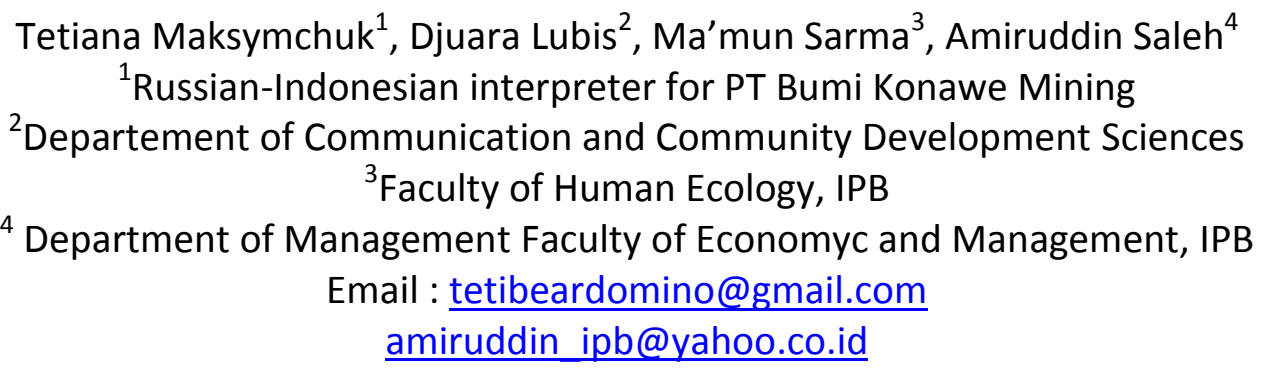

\begin{abstract}
PT Bumi Konawe Mining (PT BKM) is a company with foreign (Russian) investment which is working in the field of excavating and trading nickel ore overseas. So far, the company owns only one nickel location, in Indonesia, which is on Wowonii island, South East Sulawesi. Company works through local consultant, because the owners are foreigners, which makes local community not to trust them. So the aim of this research is to reveal which level of the CSR mechanism fails to deliver proper result. The goals for the research are (1) To analyze the satisfaction of local community members by CSR program of PT. BKM; (2) To analyze the Corporate Image of PT BKM; (3) To maintain analysis of multicultural communication of PT. BKM and describe its mechanism on the basis of their carrying out the CSR program. The method used in this research is quantitative method with a questionnaire and supported by qualitative data obtained through direct interviews with data and respondents using the guide questions. The tool used for the quantitative section is SEM (structural equation modeling). Research using significance level 0.05 or $95 \%$ confidence level. The research results reflect that age significantly influence CSR Program, which means the younger the age, the bigger the satisfaction of the CSR Program. CSR program also significantly influence the Perception of the Company by local community members, if the value of a CSR program increases, so does the value of Perception of the Company by local community members, represented by the Image of the Company and Cross-Cultural Communication.
\end{abstract}

Keywords : CSR, Crosscultural communication, foreign investment, mining

\section{ABSTRAK}

PT Bumi Konawe Mining (PT BKM) adalah perusahaan dengan investasi asing (Rusia) yang bekerja di bidang pengolahan bijih nikel dan perdagangan luar negeri. Sampai saat ini, perusahaan memiliki hanya satu lokasi nikel, di Indonesia, yang di pulau Wowonii, Sulawesi Tenggara.Perusahaan bekerja melalui konsultan lokal, karena pemilik adalah orang asing, yang membuat masyarakat setempat untuk tidak mempercayai mereka. Tujuan utama penelitian ini adalah mencari tahu mengapa mekanisme CSR gagal untuk menyampaikan hasil yang tepat. Tujuan penelitian adalah (1) menganalisis kepuasan masyarakat lokal dari program CSR PT BKM; (2) menganalisis Corporate Image PT BKM; (3) menganalisis komunikasi antar-budaya PT BKM dan menjelaskan mekanisme pelaksanaan program CSR mereka. Metode yang digunakan dalam penelitian ini adalah metode kuantitatif dengan kuesioner, didukung oleh data kualitatif yang diperoleh melalui wawancara langsung dengan data dan responden menggunakan pertanyaan 
panduan. Alat yang digunakan untuk bagian kuantitatif adalah SEM (structural equation modeling). Penelitian menggunakan tingkat signifikansi 0.05 atau tingkat kepercayaan 95\%. Hasil penelitian merefleksikan, bahwa usia berpengaruh signifikan terhadap program CSR artinya semakin muda usia maka semakin meningkatkan kepuasan terhadap program CSR. Program CSR juga berpengaruh signifikan terhadap persepsi anggota masyarakat lokal terhadap Perusahaan, jika nilai Program CSR yang tinggi akan semakin meningkatkan persepsi anggota masyarakat lokal terhadap Perusahaan yang digambarkan oleh citra perusahaan dan komunikasi lintas budaya.

Kata kunci : CSR, investasi asing, komunikasi lintas budaya, pertambangan

\section{INTRODUCTION}

CSR (Corporate Social Responsibility) is a new dimension of PR (Public Relations) that is used to reduce the corporate functions from being generating profit to that of caring for the community. The concept of CSR has acquired such significance that today it is strategically driven, operationally designed and tactically practiced in global business environment (Masuku and Shava 2014). In this respect, growing regulatory pressure on issues concerning waste, pollution and occupational health and safety in particularly dangerous activities has played an important role. This, together with social and legal demands, has meant that more awareness has been raised with regard to these matters (Vintro and Comajuncosa 2009).

Mining sector fell into the focus, as it can become a vast example of topic that will be developed and even more peculiar, the experience of foreign companies (Russian) in the mining sector in Indonesia will be investigated.

In Indonesia there are a lot of levels of stakeholders involved, when it comes to business matters, starting from central government, Ministers, governors, local MPs and up to local people. In all the levels a company has a high potential of miscommunication, which will most possibly result in business failure. That is why, a lot of companies pay special attention to the PR division of the company (Ghobadian et al. 2015).

Therefore, the smooth collaboration between Indonesian part and a foreign one is very important, especially when it comes to local communities, where foreign countries have to fulfill CSR. From the community's perspective, the CSR programs of mining companies provide a mechanism of compensation for the social and environmental costs associated with mining. These costs are usually associated with environmental impact, higher food and housing costs, and social impacts from an increase in the number of workers living in the area. Since local communities may not see many of the direct benefits from the mining industry, CSR programs are a means through which a mining company can be seen to actively give back to the community. (Kolk and Lenfant 2013).

PT Bumi Konawe Mining (PT BKM) is a company with foreign (Russian) investment which is working in the field of excavating and trading nickel ore overseas. So far, the company owns only one nickel location, in Indonesia, which is on Wawonii Island, South East Sulawesi (Sulawesi Tenggara). 
The company obtained all the required legal documents in order to start working at a mining area, such as mining license and forestry license. But PT BKM's work was opposed by the local community. During last 5 years the company has put a lot of efforts in order to improve company's image by means of several socialization programs, with the help of local consulting teams or even with the help of a contractor's team. The main reason, why the owners refuse the idea to work directly with a local community is the fact that owners are foreigners, which makes local community not to trust them. It is much easier for local people to cooperate with local consulting team, rather than with foreign team (PT Business Risk 2014).

Subsequently, all the attempts to create working relationship with community failed so far. The aim of this research is to reveal which level of the CSR mechanism fails to deliver proper result.

A lot of multinational companies face local and global issues while performing CSR activities in many countries (Husted, Allen 2006). As on several levels there was communication between foreign management with other stakeholders we would like to count upon finding on cross-cultural communication. Cross-cultural communication deals with the comparison of different cultures. In cross-cultural communication, differences are understood and acknowledged, and can bring about individual change, but not collective transformations (Ybema and Byun 2009).

\section{Logical Framework}

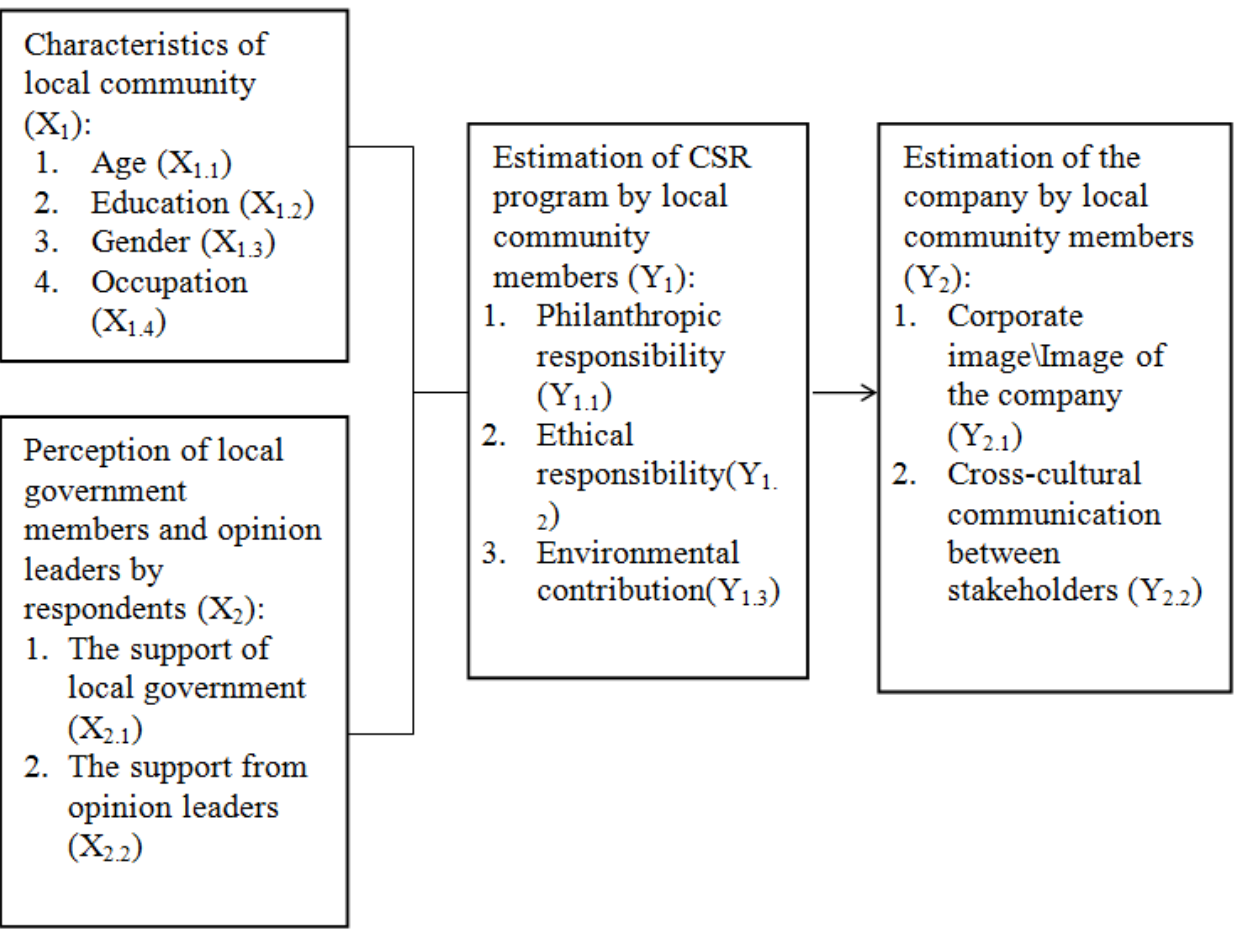

Figure 1 Logical framerwork of research, 2016 


\section{METHODOLOGY}

Design of the research is based on a mixed research - one part is quantitative, another is qualitative and it embraces two aspects. The qualitative concerns the satisfaction CSR program receivers, where receivers are people of the local community of Wawonii, South-East Sulawesi and we will research their satisfaction towards CSR program carried out by a mining company, it will be carried out in the form of questionnaire. Second part - a qualitative research and it is the estimation of cross-cultural relation between a third party - which is consultant or PR team - and a company. It is quite appropriate for this research, as it will show both numerical and narrative form of the study. The location of the research is east coast of Wawonii island, Kabupaten Konawe Kepulauan, the province of Sulawesi Tenggara. There are around 9 villages, affected by the project with 6 main villages: Nambo Jaya, Saenoi Indah, Wunse, Mosolo, Sinar Mosolo and Sinaulu (PT Business risk 2014).

The place of research is Nambo Jaya with total population of 441, and also Mosolo and Wunse - with total population of around 4000 people. The villages chosen, because of their distance to a mining site and their role among other communities. The time of the research is November 2016, where in November, was carried out a field-trip to Wawonii Island, visiting main villages near mining location.

The primary data was obtained from the answers to questionnaire from the people of the local community of south-east Wawonii. The qualitative part includes direct interviews with consultant teams, members of the company and opinion leaders. All the data is also supported by the inner-company documents, reports, journals and educational theoretical materials.

Table 1: Results of Criteria of Model of Correspondences of SEM

\begin{tabular}{lccc}
\hline \multicolumn{1}{c}{ Goodness-of-Fit } & Cutt-off-Value & Result & Conclusion \\
\hline RMSEA & $\leq 0,08$ & 0,078 & good fit \\
GFI & $\geq 0,90$ & 0,97 & good fit \\
AGFI & $\geq 0,90$ & 0,93 & good fit \\
CFI & $\geq 0,90$ & 0,97 & good fit \\
NFI & $\geq 0,90$ & 0,92 & good fit \\
\hline
\end{tabular}

Test of the validity of this research was carried out by one shot method in which the questionnaire was given to respondent once and then the data was analyzed. If the question is valid then it is used for subsequent discussions in the work and if the question is not valid the question is ignored or discarded. The analysis was performed with the help of the program Statistical Package for Social Science (SPSS) for windows 16. According to Pratisto (2004) this test is called internal consistency test in which the measurement is done once. Decision-making based on the validity of the attribute value ( $r$ count) compared with the $r$ value from the table or a probability value ( $p$-value). Attributes declared invalid if the correlation coefficient ( $r$-count) $>r$-table or a $p$-value $<$ 0.05 . The $r$-table for $n=30(d f=28)$ is 0.361 . Thus the entire $r$-count (correlation coefficient) obtained from the processing of research data is more than $r$-table. 
Validity test results on early stage show that all the attributes of each dimension are valid (legitimate). Thus all the attributes (variables) can be used for further discussion.

Data, obtained is analyzed with the following statistical procedure:

(1) Descriptive statistical analyses. The descriptive analyses is used to describe data in general using frequency, percentiles, percentage, average, average score and total average score.

(2) SEM - structural equation modeling. In this study, SEM analysis is performed using LISREL 8.3 software. Suharjo (2007) uses the size of the conformance criteria of the overall model (overall model fit) with parameters such as Goodness of Fit Index (GFI), Adjusted goodness of Fit Index (AGFI), Root Mean Square Residual (RMR), and Root Mean Square Error of Approximation (RMSEA). After some modifications with caution were made, we obtained the value of the overall conformance after testing the model against these indices as shown in Table 1 below. From the values obtained, the whole model built has a corresponding value, so that model is able to explain the information corresponding empirical data, which was collected.

Processing results for testing the goodness of fit using testing RMSEA generate value $0.078 \leq 0.08$ which means that the resulting model is already good fit. The use of other criteria that are a good fit GFI, AGFI, CFI and NFI generate value $\geq 0.90$, which means the resulting model is already good fit. The test results of several indicators measuring goodness of fit model resulted in the conclusion that the model has met the criteria of goodness of fit, so the theory of hypothesis testing can be done.

\section{RESULTS AND DISCUSSION}

\section{Information about company and community}

The Wawonii Laterite Nickel Project is located at Mosolo and Polara District, Konawe Region, Southeast Sulawesi Province - Indonesia. Total license area coveres 3,175 ha. Exploration and production (IUP) permit owned by PT Bumi Konawe Mining was issued 2007 and amended in 2010 (Dewi 2015). The company has experienced few problems while they were trying to enter and work in mining site. In 2009 while the PT BKM team was working in the area the arson attack took place. After 2009 there have been several waves of socialization through different local CSR team in 2011, 2013, 2014 and the last one in 2015. But the local community still refuses any activity of the company.

The first CSR team started working in the area before the Russian company bought $70 \%$ of the shares. The CSR team that was carrying out socialization was a part of the contractor team, which was making test-pit boring in the area near Mosolo village. It consisted of few people, including the head of a technical and construction department. They lived among villagers and had quite good relationship with them until 2009 arson attack. Their team focused on giving work places for villages and making few donations on religious and traditional holidays. It is hard to say what was the main reason for initial breakdown in 
relationship, but after 2009, community of Mosolo village has never accepted any cooperation.

Second CSR team consisted of only few people, and two of them were originally from Wowonii. The chief of the team was from South Sulawesi, working for the consulting company and was hired by a first Russian director in 2011. They also were living in Mosolo. In Nambo Jaya, Mosolo and Wunse they were well accepted by community members because of their personality style. However chief of CSR team appeared to be a little disorganized and possibly easily influenced (PT Business risk 2014). The turning point was when the community demanded to raise the price for clove tree compensation and a new CSR chief gave the documents with new fixed compensation fee (which was 6 times higher than normal and was impossible to be fulfilled by a company) to a Russian director for a signature. The director claims, the document signed was in Indonesian language, so he didn't know what he was signing. After this, community perceived that company isn't trustworthy.

Next socialization wave happened in 2013, and with a head of technical department in chief, who was appointed by a new contractor team. Their CSR program seemed to work well, as they helped community, to build some water and toilet facilities and also with communication between villages. The team was well received and management decided it was time to renew boring. Russian team came to the island with heavy boring equipment and were forced to flee an island via sea, because Mosolo villagers opposed and tried to burn the equipment. Part of the equipment was hidden by the Nambo Jaya community members, loyal to the company.

In 2014, Russian shareholders initiated to change top management and new Russian director was appointed. During 2014 and 2015 there were two more waves of socialization (PT Business Risk 2014). In 2014 the CSR team was formed with a help of specialized mining consulting company, which had also connections in local Wawonii government. They promised to end opposition of villagers in three months. They didn't risk to put their headquarters in Mosolo and preferred to start socialization from the most distant village of the mining areal - Sukarela village. They tried to donate some money for charity, religious and sports events. They also hired few villagers to help them.

For the future they were planning a lot of CSR activities, including building the road between villages, building mobile hospitals and training village members in farming, driving heavy equipment and giving other specific training, so that later on these people could work for the company as well. They were making weekly reports with good results, but management decided to stop working with them, because team was focused only on Sukarela village, which was strategically not important and they didn't try to maintain any relationship with main villages of Mosolo, Nambo Jaya and Wunse, although in their contract it was specifically mentioned.

The last socialization took place in 2015 and was carried out by a team of military and ex-police members. Few trips were made together with Russian management, people had a chance to have an open dialogue with Russian man 
in chief, there was a questions-and-answers section, head of the technical department was explaining people the technical part of mining plans, educating them and in the end, people were given some gifts for the community of each village. This team has built mini libraries in two of the villages and donated cows to each village for Idul Adha ceremony. The chief of CSR refused to continue socialization after talking to the main Mosolo members (including head of the village and his family) and receiving very strong opposition. He concluded that villagers don't want mining in their area, because they are comfortable with their income from cloves. He recommended selling this project and buying a new one on another island.

Nearly all of the community members within the client's IUP on the east coast of Wawonii Island are originally from Buton, some distance to the south of Wawonii. Though the east coast of the island is dominated by ethnic Butonese, there are 72 languages in their native Buton with many of these languages being very different. Mosolo and Nambo Jaya are dominated by Cia Cia Butonese whereas Munse is dominated by Kulisusu Butonese.

\section{SEM}

This study is using a significance level 0.05 or a confidence level of $95 \%$. Figure 2 shows almost all variables have a value of $t>1.96$, except on X1.2 indicator (education) has a value of $t<1.96$ indicates that education is not significant to reflect/describe $X 1$ to influence Y1. As SEM can deal only with ordinal data, we couldn't include 2 indicators of characteristics of local community members, because the data they represent is nominal. Those indicators are X1.3 - gender, X1.4 - occupation. Although not included in SEM, this data will be discussed using descriptive statistics.

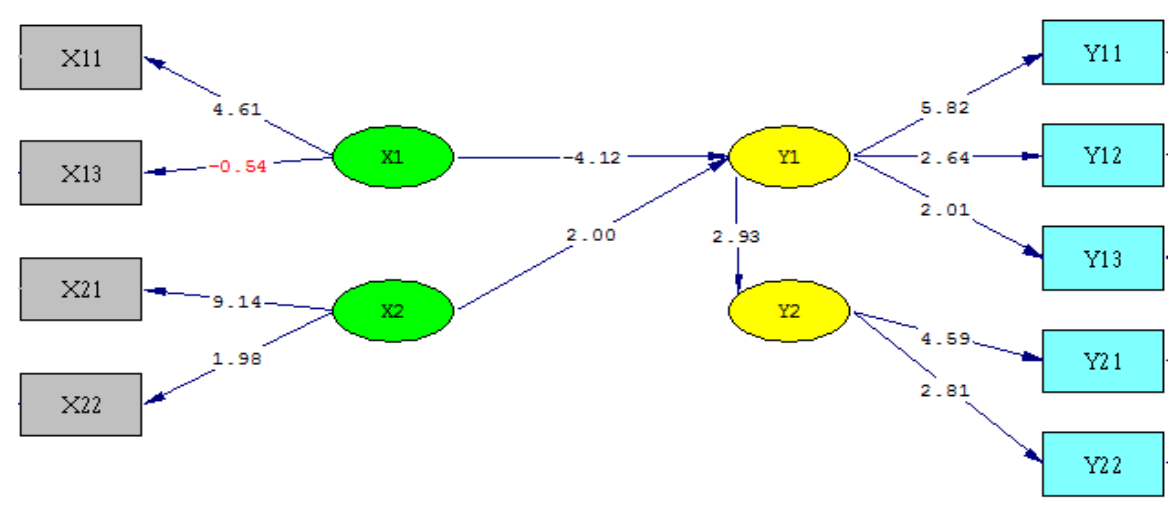

Chi-Square $=33.91, d f=20, \quad P-$ value $=0.02677$, RMSEA $=0.078$

Figure 2. Value t of SEM Model

Figure 3 shows the results of testing the hypothesis that $\mathrm{X} 1$ (Characteristics of the local community) is reflected/illustrated by a significant effect on the age of Y1 (CSR program) amounted to -0.35 meaning the younger the age, the bigger the satisfaction of the CSR program is. In addition, X2 (Perception of local government members and opinion leaders) also have significant effect on $\mathrm{Y} 1$ 
(CSR program) of 0.13 meaning that the higher the support of government and community leaders the better is the effect of the $\mathrm{Y} 1$ (CSR program). CSR program also has a significant effect on $\mathrm{Y} 2$ (Company estimation by local community members) of 0.76 , meaning that the CSR program (Y1) which is reflected by the Philanthropic responsibility, Ethical Responsibility and Environmental contribution that higher is the score the more they would increase Y2 (Perception of the company estimation by local community members) which reflected/illustrated by Corporate image and Cross-cultural communication. In simple words, the better CSR program, the better is Corporate Image of the company and more smooth cross-cultural communication. Loading factor value in Figure 3 also shows the contribution of each indicator variable towards latent variables. X1.1 (age) predominantly reflects X1 (Characteristics of the local community), X2.1 (The support of local government) predominantly reflects X2 (Perception of local government members and opinion leaders), Y1.3 (Environmental contribution) predominantly reflects Y1 (CSR Program) and Y2.1 (corporate image) reflects the dominant Y2 (Perception of the company by local community members).

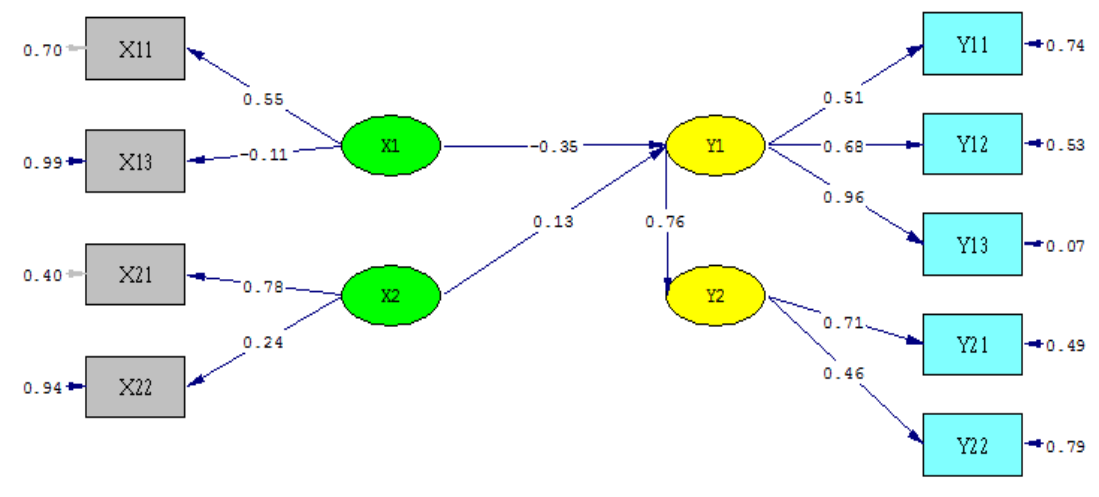

Chi-Square $=33.91, \mathrm{df}=20, \mathrm{P}-$ value $=0.02677, \mathrm{RMSEA}=0.078$

Figure 3. Loading factor of SEM Model

\section{Characteristics of local community}

This variable included age, gender, occupation and education. After two of the indicators were tested by SEM model, it showed that age was very significant and it showed that younger population of local community have tendency to have more positive perspective on CSR program of PT BKM, and as the result on the company's activity in general, rather than older people. This may also be proven by the results that have been obtained from direct interview with ex head of CSR team of PT BKM, who stated that a lot of young people welcome foreign investor, as they have hope to find new job opportunities and also hope to have better infrastructure around their place of living.

Education as an indicator was discarded, as being insignificant to a research, although it is still important to notice that the majority of population (58.3\%) have obtained high school certificate and shocking $35.7 \%$ of population have education less than high school with only $6.1 \%$ of population striving to get into higher institutions. This also creates quite few challenges for the company, when 
planning their CSR program. First of all, the amount of schools in the area is not satisfying and SD (elementary school), SMP (junior high school) and SMA (high school) are often situated in different villages, so local children have to walk quite far to school each morning. This, together with poverty issues often pushes young people to leave school and search for a job (PT Business risk 2014).

We may also rely on the words of ex head of CSR team of PT BKM, as one of their biggest focus became an enlightenment of local community, because as they stated in their primary report, one of the issues that caused conflict in 2009 and afterwards, has been a lack of information, the community received both about mining proses and about foreign investors. It was even stated: "Some of people around a mining site still are convinced that mining will cause an island to drown". For that reason the company has provided a mini library for one of the villages with the aim for people to self-educate and filled it with books, including the books about mining as well.

As for other two indicators of X1 (Characteristics of Local Community), should be admited that gender is predominant by a male against female respondents, subsequently $64.3 \%$ male respondents and $35.7 \%$ of female respondents.

The indicator of occupation tells us a lot about local community as of people mostly occupied in the field of agriculture, with almost $79 \%$ being farmers as we can observe on the Figure 4. Although, if we check the data on occupation from the company's documents, we can notice that the percent correlation is quite different with as much as $60 \%$ of working community members deriving their income from fishing and $40 \%$ from farming in Nambo Jaya village. Cloves (cengkeh) are the main crop grown followed by chocolate (cocoa). In Mosolo the mainstay of the economy is cloves (cengkeh) production. It is believed to contribute to over $80 \%$ of the village economy. A number of other crops are produced that are sold. Fish are caught daily but none are sold outside the village. In Wunse $90 \%$ of the village income is from farming. Cloves are the main crop but they also farm and sell nutmeg and coconuts. Many from the community fish; but the produce is consumed within the village (PT Business risk 2014).

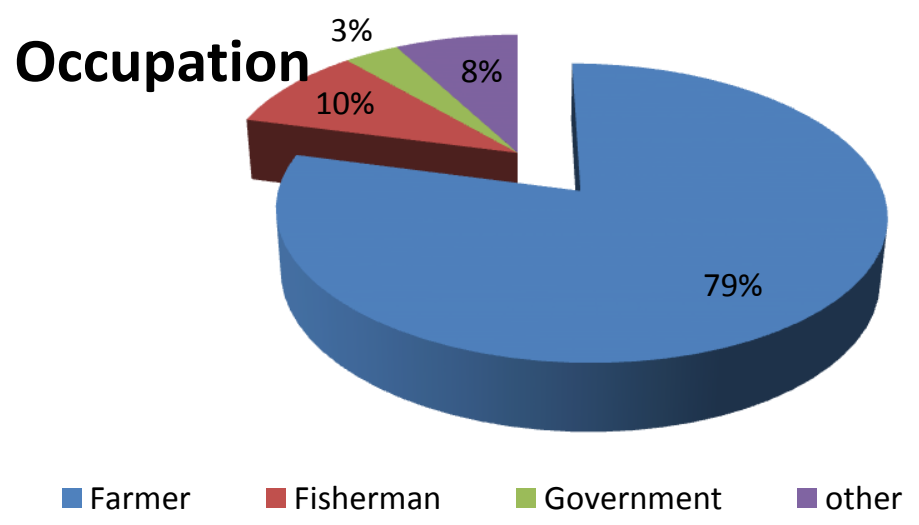

Figure 4. Occupation of local community 


\section{Perception of local government members and opinion leaders}

The findings of this study have shown that the higher the support of local government and opinion leaders, the better is the impression of CSR program by local community. On average, the majority of local community estimates the support of local government and local opinion leaders as middle $(49.6 \%$ and $74.8 \%$ ). It is confirmed by a member of local government that it is easier for a company to gain respect of a local community if company's team members are accompanied by a representative of local government or opinion leaders. But as an interview with company members has shown, Russian members are not very easy to search for a help of local government leaders as they are afraid to be associated with political games, as many politicians approach the company's chief in order to gain support for future election campaign.

On the contrary, company prefers to get some good working relationships with mining department and local opinion leaders trying to gain support and to spread information about mining in general and PT BKM's future activities in general. There were few attempts by a company's team to reach out and maintain dialog with LSM leaders, as they state to represent and advocate local community.

\section{CSR Program}

The following variable - CSR Program consists of Philanthropic, Ethical and Environmental responsibility. There are few more aspects of CSR program that will be further developed in our work with the help of interviews and other documents, those aspects include Legal and Economic responsibility. Nevertheless at the moment we can draw some conclusions on already existing results, as the quantitative part of our study shows that CSR program depends on support of local government and community leaders and in case of PT BKM, is mostly represented by an environmental support by PT BKM.

We might draw some conclusions here that are supported by the report of one of the CSR teams of PT BKM, which stated that during pre-socialization proses there were some concerns voiced by local community members, about environmental issues. Among them: Test pit holes consisting of \pm 30 holes, not closed with soil (in this case the contractor/consultant PT. BKM before), thus endangered the life of local community members who indulge into work on the areal of test pit". Interview with PT BKM's director revealed, that the Head of Technical department checked for the open test pit holes and they were bored by another company, whose IUP (mining license) is bordering with PT BKM's territory. Such a technical mistake has led to people falsely blaming PT BKM for endangering people's life, therefore brought miscommunication between community and PT BKM.

\section{Company's estimation by local community members}

It is illustrated by Corporate image and Cross-cultural communication. The results show, that there is a strong influence on both indicators by a CSR program, with dominant on the image of the company. The example of total general opinion on company in general we can observe on the following Figure 5. 
In general, the opinion leader from mining area, explains that people in the area want to have an investor in the area, but they have lost their trust in PT BKM, because there have been several years of miscommunication and pauses in the work of PT BKM. In general, what community wants is a consistent work in the area. A great attention should be paid to an issue of Cross-cultural communication. The definition of subjective culture also provides a base for defining "diversity" in a way that includes both international and domestic cultures at different levels of abstraction (Bennett 1998).

The study has supported our concern about the connection between a success/failure of CSR program and the miscommunication between some or all of the stakeholders, originating from different cultural background. As we learned to know from the company member, that during last few years, company management, which consists of Russian people, has chosen to work with the help of a local CSR teams in the field, because local community makes contact easier with local team, rather than foreign representatives.

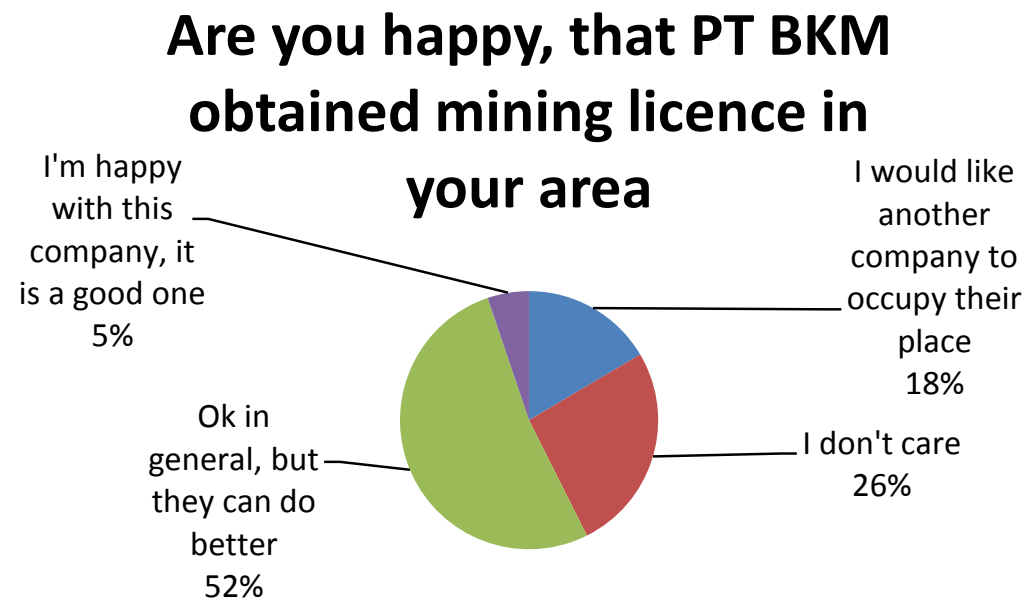

Figure 5. Company's image

Unfortunately, at the same time, this added one more link between company and local community, which made the whole process much longer. According to a company member, some of the CSR teams were making unrealistic promises to a community, without asking the permission from management. As the result, it influenced the trust issues with the community.

As we can see from an interview with the present Russian management of PT BKM, local team is hard to supervise because all the management is in Jakarta, while the team works in the field. The instructions given to a team are often misinterpreted or ignored, an example was with the team of 2014, when management emphasized several times, that the key village for socialization was Mosolo, but the team continued to focus only on Sukarela village. In their defense the team members stated that company demands fast results, which will only scare the community. Here, we can see the difference in social and cultural traditions. 
It is a custom in Russian companies to obey the top management without any negotiations and it is perceived as a sign that a worker is not trustworthy if one declines to subordinate to a person in chief. But in Indonesia the work relationships are more flexible and are open for bargaining if there is a necessity to do so. Also, as we were acknowledged by a Russian party, Russian businessmen always count on the top to bottom system of work, because it is traditionally functioning in Russia. It is usually enough to contact only main authorities of the region in order to gain the access to the territory. Paying less attention to the bottom stakeholders is another mistake of the Russian management.

\section{CONCLUSIONS AND RECOMMENDATIONS}

\section{Conclusions}

To sum it all up, we would like to say, that our study has shown the connection between the CSR program and Corporate Image, as well as the connection between CSR Program and Cross-cultural Communication and it also has illustrated the range of problems a foreign company may face, while doing business in Indonesia. The satisfaction of local community members by CSR program of PT. BKM in Wawonii island, South-East Sulawesi was analyzed in this research. Apart from that the Corporate Image of PT BKM in Wawonii island, South-East Sulawesi was analyzed as well as created analysis of cross-cultural communication of PT. BKM and described its mechanism on the basis of their carrying out the CSR program in Wawonii island, South-East Sulawesi.

\section{Recommendations}

In our opinion, company members should try to include some people from management in a CSR team, in order to eradicate miscommunication, even though it may be more challenging for a foreign team member to try and communicate with local community, but it as well may improve both perception of PT BKM by local people and results of CSR

PT should use more down-top type of communication, starting to gain trust of local community first and then focus on government, bupati etc. This may also bring positive outcome for their activity.

\section{LITERATURE REVIEW}

Bennett M.J. 1998. Intercultural Communication: A Current Perspective. In Milton J. Bennett (Ed.), Basic concepts of intercultural communication: Selected readings. Yarmouth, ME: Intercultural Press;

Ghobadian A., Money K., and Hillenbrand C., 2015. Corporate Responsibility Research: Past-Present-Future. Journal, in Group \& Organization Management 40(3):271-294;

Husted B.W. and Allen D.B. 2006. Corporate Social Responsibility in the Multinational Enterprise: Strategic and Institutional Approaches. Journal Of International Business Studies, 37 (6). pp. 838-849; 
Kolk, A., and Lenfant, F. 2013. Multinationals, CSR And Partnerships In Central African Conflict Countries. Corporate Social Responsibility and Environmental Management, 20, 43-54;

Lewin, T. 1983. Business ethics' new appeal. New York Times, December 11:F3;

Masuku C. and Shava T. 2014. Practices and approaches of corporate citizenship by Public Relations (PR) department at Nestle Zimbabwe to enhance corporate reputation from 2010 to 2013. International Journal of Innovative and Applied Research, Volume 2, Issue (2): 32- 46

Pratisto A. 2004. Cara Mudah Mengatasi Masalah Statistik dan Rancangan. Percobaan dengan SPSS 12, Elex Media Komputindo, Jakarta. Ghozali, Imam.

PT Business Risk Indonesia, 2014. Stakeholders mapping and research. Private Confidential Research for PT BKM, Jakarta;

Vintro C., Comajuncosa J. 2009. Corporate Social Responsibility in the Mining Industry: Criteria and Indicators, Dyna 77(161): 31-41;

Ybema S. and Byun H. 2009. Cultivating Cultural Differences In Asymmetric Power Relations. International Journal of Cross-Cultural Management 9(3): 339-358; 